\title{
Køn som infrastruktur
}

I den danske velfardsstat er kon fastsat som en grundlaggende promis, alle borgere skal klassificeves ud fra. Artiklen undersoger betydningen af de formelle kønskategorier indlejret $i$ en omfattende infrastruktur, der ordner det danske samfund og fär bverdagen til at glide uproblematisk - for de fleste.

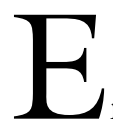

n grundpræmis for at blive anerkendt som borger i Danmark er, at ens køn kan defineres inden for oppositionsparret mand/kvinde. Det er ganske enkelt ikke teknisk muligt at blive registreret som borger uden samtidig at blive formelt klassificeret som værende det ene eller andet køn, samtidig med at det er næsten umuligt at ændre klassificeringen efterfølgende. Artiklen vil argumentere for, at dette er en konsekvens af, at de to kønskategorier danner grundlag for en lang række forhold i samfundet, der opstiller utvetydig klassificering af borgere efter køn som $\sin$ forudsætning. For kønsklassificeringen forgrener sig ud i hverdagen og indgår i en omfangsrig og usynlig infrastruktur, der 'ordner' den sociale verden og underbygger kønskategorierne som selvfølgeligheder.

Den formelle kønsklassificering er alligevel blevet genstand for kritik igennem de seneste år, da især transkønnedes problemer med ikke at 'passe ind' i institutionaliserede 
forståelser af køn er bragt ind i Folketinget. Over de næste sider vil artiklen udforske, hvordan en klassificering, der har omfattende betydning for livet som borger i Danmark, formår at stå næsten helt uproblematiseret hen og kun blive tillagt betydning af de, der lever i kønnenes grænseland.

\section{AT STUDERE DET SELVFØLGELIGE}

For analytisk at kunne gå til de formelle kønskategorier og disses betydning for hverdagen i Danmark har undersøgelsen taget sit afsæt i CPR-nummeret. Det unikke ved dette nummer er, at vi her finder kønsklassificeringen konkretiseret $\mathrm{i}$ det sidste ciffer; lige tal angiver 'kvinde', ulige tal angiver 'mand'. Klassificeringen er ufravigelig og så godt som uforanderlig; kun "fejl i de oplysninger, der indgår i deres personnummer" giver mulighed for en xndring i CPR-nummerets kønsangivelse (LBK 878 af $14 / 09 / 2009$ \$ 3 ).

Med CPR-nummeret som omdrejningspunkt har undersøgelsen søgt at kortlagge kontroverserne omkring nummerets indlejrede kønskategorier; en metodologi, der kan skabe ontologiske forstyrrelser i hverdagens selvfølgelige elementer og dermed skabe mulighed for nye bevidstheder (Whatmore 2009). Via artikel- og internetsøgninger blev det dog hurtigt tydeligt, at dette bestemt ikke er et omdiskuteret emne. Kontroverserne omkring CPR's kønsklassificering har primært været udgjort af kritikker ytret af politiske partier på venstrefløjen og interesseorganisationer, der fokuserer på transkønnedes vilkår. Intentionen bag undersøgelsen har ikke som sådan været at studere kønnenes grænseområde eller transkønnedes forhold i Danmark. Men italesættelser af og diskussioner omkring CPR-nummerets kønsopdeling har vist sig primært at kredse om denne mangfoldige gruppes rettigheder og muligheder. ${ }^{1}$

At 'anvende' transkønnethed som tilgang til et studie af kønskategorierne er ik- ke uproblematisk. For eksempel kritiserer den amerikanske kønsforsker Rosa Lee i bogen Why Feminists Are Wrong (2006), at transkønnede er blevet taget som gidsler i et poststrukturalistisk feministisk frihedsprojekt. At transkønnethed i øvrigt er blevet et udbredt emne inden for kønsforskningen kan forklares med den amerikanske sociolog Susan Leigh Stars begreb og teori om granselandet. Med dette begreb henviser Star til mellemrummet mellem dikotomiske, gensidigt ekskluderende kategorier som for eksempel mand/kvinde-kategorierne. I mellemrummet bliver kategorierne synlige i kraft af grenseeksistenser, såsom transkønnede, der kropsliggør og praktiserer køn på en måde, der er forskellig fra konventionelle, institutionaliserede kønskategorier. Her bliver forhandlinger og udfordringer af ellers selvfølgeliggjorte kønskategoriers grænser tydelige, fordi grænseeksistenser - som også Dorthe Staunæs' gransefigurer (2004) og Dorte Marie Søndergaards randpersoner (2000) - "remind us that, indeed, it might have been otherwise" (Star 1991: 53). Som en informant med Hans Scherfigs ord udtrykte det:

“'Det er med det nationale spørgsmål, som med ens tænder: Man tænker kun på dem, når der er problemer med dem'. Altså, hvis man ikke oplever at være i en yderposition, så stiller man ikke spørgsmålstegn. Det er dem, der er i yderpositionerne, som stiller spørgsmålstegn. De andre kører jo bare på den måde, de nu engang kører. Hvorfor skulle de lave om på det?" (Aktivisten)

Aktivisten er en af seks interviewede informanter, der alle er opstillet som karakterer for at tydeliggøre den enkelte informants position i debatten. De tilskrevne karakterer, der er formuleret induktivt, kan dog på bekostning af virkelighedens kompleksitet - ses som en indledende definition af de enkelte informanters kontekstuelle forståelse af emnet. Ud over Aktivisten indgår også Politikeren, Kønsterroristen, Tals- 
personen, Embedsmanden og Teologen som stemmer i denne artikel. Bag disse karakterer gemmer sig fire informanter, der på forskellig vis har kritiseret det kønsopdelte CPR-nummer, mens de to sidste informanter via deres beskæftigelse har stor erfaring med CPR. ${ }^{2}$

Blandt de karakterer, der har kritiseret CPR's kønsopdeling, varierer fokuspunkterne i kritikken: Mens Aktivisten og Politikeren ønsker, at kønsopdelingen afskaffes helt, argumenterer Talspersonen for en fjernelse af kønnets synlighed i selve CPRnummeret. Talspersonen vil også, ligesom Kønsterroristen, gerne have bedre muligheder for at skifte kønskategori uden nødvendigvis at ændre på selve CPR-systemet. ${ }^{3}$

Ud over disse karakterer vil artiklen være centreret omkring tre politiske beslutningsforslag om transkønnedes rettigheder, der alle problematiserer CPR-nummerets uomgængelige og (næsten) uforanderlige kønsklassificering. To af disse forslag, der alle er fremsat i Folketinget, fremsætter ønske om, at myndige borgere selv skal kunne bestemme, hvilken kønsidentitet deres CPR-nummer skal udtrykke (B 65 07/08; B 142 06/07). Et af forslagene går $\mathrm{i}$ sin begrundelse endnu videre og indstiller til, at personnumre på sigt helt skal miste deres kønsspecificitet (B 142 06/07), mens det tredje og sidste forslag fremstiller det lidt mindre radikale ønske om "en revision af betingelserne for at få ændret civilretlig kønsstatus” (B 168 09/10).

\section{PERSONREgisterets ROLLE}

Indførelsen af Det Centrale Personregister og det dertilhørende CPR-nummer i 1968 var banebrydende, idet massive mængder af informationer fra et stort antal ministerielle og kommunale områder nu blev bundet op på ét personspecifikt nummer. Samtidig har CPR-nummeret på den tekniske side uden tvivl gjort en masse arbejdsgange lettere for især myndighederne; alt fra at undersøge socialt bedrageri til at udbetale feriepenge.
For borgere betyder det også, at en adressexndring for eksempel kun skal meldes til Folkeregistret og ikke separat til kommune, læge, bibliotek, etc. Som Teologen udtrykte det: "Det er utrolig praktisk."

I forhold til hvad der registreres i selve CPR, har udviklingen dog været mindre banebrydende $\mathrm{i}$ forhold til tidligere registrering af borgerne. I CPR registreres kun hvad Embedsmanden definerede som "grundlæggende personoplysninger". ${ }^{4} \varnothing_{\mathrm{V}-}$ rige oplysninger om for eksempel uddannelse, konkurser og indkomst registreres i separate registre, der dog alle er bundet op på CPR-registrets grundoplysninger. I et komparativt perspektiv kan det danske registreringssystem omkring CPR siges at være relativt unikt, hvilket ifølge Embedsmanden er en konsekvens af den danske befolknings "tillid til myndighederne og et stærkt demokrati."

CPR-systemet har ifølge Teologen været helt centralt $\mathrm{i}$ at kunne opbygge det velfærdssamfund, man ønskede - og ønsker - i Danmark. Dermed sagt at vores nuværende velfærdssamfund ligeledes er dybt afhængigt af CPR. Dette kan anskues ud fra et økonomisk argument om, at staten for at få indkrævet et tilstrækkeligt økonomisk grundlag for at kunne tilbyde velfærd må have en solid kontrol med og et overblik over borgerne og deres indkomst (Embedsmanden). Ud fra en mere serviceorienteret vinkel er det personoplysninger i CPR, der muliggør velfærdsstatens målrettede tilbud om mammografiscreening til kvinder over $50 \mathrm{og}$ en automatisk tildeling af seks års SU til studerende, når de optages på en lang videregående uddannelse (Teologen). Endelig kan CPR også ses som eksistensbetingelsen for et massivt administrativt system, der understøtter den nuværende velfærdsmodel.

\section{INFRASTRUKTUR SOM BEGREB}

For at begribe CPR-systemets formelle kønskategoriers rolle for hverdagen i Dan- 
mark, kan vi finde inspiration hos den førnævnte Susan Leigh Star og hendes fagfælle Geoffrey C. Bowker. De to har med inspiration fra den symbolske interaktionisme og etnometodologien rettet fokus mod den formelle og uformelle klassificeringspraksis, som vi mennesker inkorporerer i verden for at kunne begå os i den. I Sorting Things Out (2000) undersøger Bowker og Star en række historiske og nutidige klassifikationssystemer, der i kraft af ønsker om sammenhæng og integration i informationssystemer samlet kommer til at udgøre infrastrukturer, der făr hverdagen til at glide uden besvær. I trafiksammenhænge betyder en god infrastruktur, at vi for eksempel kan komme fra Rønne til Herning uden for mange problemer, fordi der er skabt strukturer af motorvejsnet, broer, færger og færdselsregler, der binder landet sammen. Bowker og Stars overførsel af dette begreb på samfundet som helhed beskriver tilsvarende, hvordan kategorier gennem systemer og netværk binder den sociale verden sammen og får rejsen gennem hverdagen til at glide let og ubesværet.

Den sociale verden formes og praktiseres her gennem klassifikationer og standardiseringer ned til mindste detalje, der samlet udgør infrastrukturer, hvori mennesker, institutioner og materialitet tilsammen indgår i netværk, der skaber sammenhæng, betydning og selvfølgeligheder. Når infrastrukturen som konsekvens af dette fungerer, bliver den usynlig:

Information infrastructure is a tricky thing to analyze. Good, usable systems disappear almost by definition. The easier they are to use, the harder they are to see. As well, most of the time, the bigger they are, the harder they are to see. (Bowker \& Star 2000: 33).

Men fordi infrastrukturen insisterer på en total klassificering, da den ellers ikke på samme måde kan skabe sammenhæng og system i samfundet, bliver de standardiserede kategorier samtidig en kilde til lidelse
(Bowker \& Star 2000: 219-225, 319-320). Dette sker i kraft af, at kategorierne aldrig vil kunne favne virkelighedens mangfoldighed, men i stedet favoriserer og cementerer specifikke synspunkter, der fremstilles som selofolgeligheder, mens andre synspunkter omvendt bliver gjort tavse (Bowker \& Star 2000: 5). Dermed bliver infrastrukturens institutionalisering af kategorierne problematisk, da undertrykkelsen af synspunkter medfører fordele og lidelse - afhængigt af om man repræsenterer det, der gøres selvfølgeligt eller tavst.

\section{CPR SOM INFRASTRUKTUR}

Infrastruktur som teoretisk begreb er altså her taget fra Bowker og Star. Men sammenligningen af CPR med en infrastruktur er også anvendt blandt embedsmænd og politikere - om end i en mere snæver forståelse af ordet. Tillige med flere andre har blandt andre Lars Løkke Rasmussen i rollen som sundhedsminister relateret CPR til begrebet "infrastruktur", hvilket kom frem i følgende definition af CPR i folketingssalen:

CPR har karakter af et grundregister, som altid skal være korrekt [...] Personnummeret og CPR som sådan indeholder nogle grunddata, som er et væsentligt element i Danmarks administrative infrastruktur [...og] er i mange sammenhænge grundlaget for offentlig myndighedsudøvelse. (1. behandling af B 142 06/07)

At CPR - som det nu engang er med gode infrastrukturer - ikke er til debat på trods af dets omfattende brug, kan ses som en konsekvens af, at det som infrastruktur er blevet usynligt. Dette blev også tydeligt, da Embedsmanden konkluderede, at den eneste opmærksomhed, CPR oplever, er, at “der stilles af og til spørgsmål fra Folketinget om CPR, og fra tid til anden er der presseomtale af CPR", men at det hverken blandt befolkningen eller politikerne danner grundlag for ideologiske kampe. 
Som nævnt er der dog på forskellig vis rejst kritik af CPR's kønsklassificering; en klassificering, der har direkte betydning for den enkeltes muligheder, rettigheder, forpligtigelser og juridiske status $\mathrm{i}$ et antal henseender. Af påvirkede forhold kan for eksempel nævnes længde af barselsorlov, aftjening af værnepligt, udbetaling af børnecheck, indgåelse af rgteskab, automatisk tilskrivning af forældremyndigheder, tilbud om undersøgelser og behandlinger i sundhedsvæsnet og hvilket fornavn, man kan tage. Lovgivning, strukturer og praksis omkring alt dette er bundet direkte op på det køn, borgeren (og muligvis også vedkommendes partner) er klassificeret som i CPR.

Klassificeringen af køn i CPR sker konkret ved, at der sættes et flueben i enten kategorien 'dreng' eller 'pige' ved oprettelsen af en ny borger i CPR's elektroniske database og er så grundlæggende, at nye borgere ikke kan registreres, hvis der ikke er markeret i en af disse to kategorier. For at en ydelse som for eksempel børnechecken automatisk kan udbetales til moderen - som det nu engang er besluttet, at den skal - er det nødvendigt, at der allerede ved registreringen af moderen i CPR mange år forinden er blevet sat et flueben ved 'pige'. Der eksisterer altså sammenhænge mellem alt fra det tekniske design bag en database over udformningen og praktiseringen af en kønsspecifik lovgivning til det at blive registreret som borger. Her muliggør et infrastrukturperspektiv forståelser af sammenhænge på tværs af mikro- og makroniveauer i samfundets hverdagsforhold. 5

Efter den første registrering i CPR er det kun muligt for borgere at få ændret kønsangivelsen i CPR-nummer, såfremt der er "fejl i de oplysninger, der indgår i deres personnummer" (LBK 878 af 14/09/ $2009 \$ 3)$. Det er i øvrigt denne undtagelse i lovgivningen, der anvendes, når en person har gennemgået kønsskifte og derved berettiger sig til at skifte kønskategori i CPR og få udstedt nyt CPR-nummer.

\section{IDEEN OM 'DET KORREKTE KØN'}

Netop fordi så mange regler og love er bundet op på køn, bliver standardiserede kønskategorier også nødvendige for at kunne skabe og opretholde en integreret infrastruktur. I en folketingsdebat om blandt andet at øge transkønnedes muligheder for at kunne skifte kønsangivelse i CPR-nummeret, fastslog Venstres Marion Pedersen således:

Samtidig foreslår forslagsstillerne, at myndige personer selv skal kunne bestemme, hvilken kønsidentitet deres personnummer skal udtrykke. Hvis det bliver gennemført, trækker vi så at sige txppet væk under vores CPR-register, som en stor del af vores samfund bygger på. (1. behandling af B 142 06/07)

Dermed sagt, at vi nødvendigvis må tænke kønsklassificeringen som gensidigt betinget af den infrastruktur, den er indlejret i. Infrastrukturens arkitektur levner ikke plads til grænselandet imellem kategorierne, her udgjort af brud med den institutionaliserede forståelse af køn.

I samme folketingsdebat understregede Lars Løkke Rasmussen i rollen som sundhedsminister, at forslagets indhold ikke ville "være i overensstemmelse med kravet om, at personnummeret og CPR som sådan skal indeholde korrekte grunddata" (1. behandling af B 142 06/07). Ud over at vi her făr konstateret kønnets grundlæggende status i forhold til registreringen af borgere, tydeliggør citatet tillige, at CPR er baseret på en ide om, at det er muligt at definere og registrere en borgers "korrekte" køn - dette værende sig inden for én af de to standardiserede, gensidigt udelukkende kategorier.

Hvis vi ser nærmere på, hvordan kønsklassificeringen i CPR-nummeret sker, viser det sig, at dette 'korrekte' køn afspejler forståelser, der er koblet til Michel Foucaults formuleringer om det sande køn; ideen om at et menneske kun kan kropsliggøre ét af to gensidigt ekskluderende køn, hvilket kan 
klarlægges ved hjælp af videnskaberne. Dette sker i forhold til kønsklassificeringen i CPR oftest ved jordmoderens konstatering af den nyfødtes biologiske køn umiddelbart efter fødslen. Her knytter videnskabernes normativitet sig til biologien, hvorved kønnet fremstilles som biologisk determineret (Foucault 1981, 1994). Dette bekræfter Politikeren, som har talt for, at myndige mennesker selv kan bestemme, hvilken kønsidentitet deres CPR-nummer skal udtrykke. I folketingsdebatten omkring beslutningsforslaget B 142 06/07 oplevede han, at forstålsen af køn som en biologisk sandhed er "fuldstændig dominerende [...] $\mathrm{Og}$ der tror jeg, at Folketingets sammensætning... altså, der er ingen forskel mellem det, og hvordan det er ude i samfundet i al almindelighed." Men CPRnummerets kønskategorier giver også netop mening, fordi de læner sig op ad normative forståelser af $k ø n$ i det danske samfund. De er ikke taget ud af ingenting, men må ses som en effekt og underbyggelse af forståelser af køn i det samfund, de er konstrueret inden for (Bowker \& Star 2000: 60-64). Alt dette er med til at fremstille det biologiske køn som "radikalt ukonstrueret", som Judith Butler beskriver det i klassikeren Gender Trouble (1990: 7).

At det som nævnt er næsten umuligt at få lov til at skifte kønskategori kan derfor siges at være betinget af, at den bagvedliggende forståelse af køn er centreret om biologi og køn som en "medfødt omstændighed" (Lars Løkke Rasmussen, 1. behandling af B 142 06/07). Indlejret i en omfattende infrastruktur bliver ideer om det sande, biologiske køn samtidig understøttet af behovet for utvetydig klassificering. Infrastrukturen lever altså højt på normative forståelser af køn som et dualistisk fænomen.

\section{KATEGORIERNES NEGATIVE SLAGSIDE}

At CPR stiller krav om, at alle borgere skal defineres utvetydigt som enten det ene eller andet $\mathrm{k} ø$ og leve op til ideer om et biologisk determineret køn, bliver dog problematisk for de, der ikke 'passer ind' i kategorierne. Disse borgere bliver gjort tavse og må påtage sig lidelse, fordi de stilles uden for det institutionaliserede system (Bowker \& Star 2000: 319-326). At være 'uden for' betyder i denne sammenhæng ikke, at man ikke tildeles et CPR-nummer eller statsborgerskab. Men i kraft af ikke at 'leve op til' ens klassificering anerkendes man ikke på lige fod med andre borgere. Dette kan forstås som et konkret udtryk for teser om, at den enkelte altid er i relation til dominerende diskurser og vurderes ud fra dem, selv om vedkommende ikke indtager en accepteret position (Butler 2004, Foucault 1994). Den manglende anerkendelse kommer for transkønnede til udtryk ved fraværende rettigheder og forståelse, lidelse, utallige spørgsmål, frustrationer og vold. En transkønnet informant udtrykte således frustration omkring passets kønsangivelse:

Det er jo det, jeg har oplevet: De [lufthavnspersonalet] bliver forvirrede. Det er jo ikke fordi, jeg ikke får lov til at komme med, men der sker for mange forvirringer og det gør jo, at man føler sig udsat, sårbar [...] Hvorfor skal jeg være i alles søgelys og glos på, kigges på? (Kønsterroristen)

Sådanne situationer har gennem min empiriske indsamling vist sig gennemgående i beskrivelser af transkønnedes møder med kønsklassificeringen i officielle registre, der i øvrigt alle er koblet op på CPR. Talspersonen kunne på baggrund af sit politiske arbejde med emnet og personlig erfaring ligeledes bekræfte, at det medfører både pinlige og ubehagelige situationer, når man som transkønnet konfronteres med den kønsklassificering, der er angivet i pas, kørekort og sygesikringsbevis. Men også selve det, at for eksempel interkønnede 'tvinges' ind i én af de to kønskategorier, bekymrer ham; en tvang, der er udtryk for en manglende erkendelse af, "at det ikke er 
naturgivent at være kun mand eller kun kvinde" (Talspersonen). Denne problematik vurderer han i øvrigt også - ligesom Kønsterroristen - som værende aktuel for transkønnede, da mange transkønnede "har det bedst i midten" (Talspersonen).

At klassificering har produktive aspekter stilles der ikke spørgsmålstegn ved hos Bowker og Star, da de argumenterer for, at det er nødvendigt at klassificere hverdagen ned i detaljen, for at vi overhovedet kan gå til og begå os $i$ verden. Men med det moderne bureaukratis omfattende brug af klassificeringssystemer er det nødvendigt at skabe større refleksion og tydelighed omkring grundlaget for disse (Bowker \& Star 2000: 37-39). Når CPR og dets dertil hørende kønsklassificering defineres som "praktisk" af blandt andre Teologen, bør vi derfor spørge: Praktisk for hvem?

\section{INFRASTRUKTURENS KONSEKVENSER}

At CPR's kønsklassificering ikke levner plads til grænseeksistenser tydeliggøres og begrundes i følgende citat fra Det Konservative Folkepartis Vivi Kier, der under folketingsdebatten om et beslutningsforslag, der fremsatte forslag om, "at myndige mennesker selv kan bestemme, hvilken kønsidentitet deres CPR-nummer og pas skal udtrykke" (B 65 07/08) tydeliggør den svære situation, transkønnede er fanget i:

Der vil jeg sige, at jeg har stor, stor forståelse for, at man kan være født i en krop, som man ikke synes er af det køn, man gerne vil være [...] Men lige nøjagtig den måde, vi udøver myndighed på i Danmark, er jo fuldt og helt baseret på CPR-nummeret, og jeg har svært ved at se, at det bare sådan lige ganske, ganske enkelt kan ændres [...] Derfor afviser vi forslaget. (Vivi Kier, 1. behandling af B 65 07/08)

Problemet ligger ifølge Bowker og Star i den perfektion, klassifikationerne tilstræber, hvorved den reelle, bagvedliggende mangfoldighed bliver gjort usynlig (2000: 319326). De borgere, der ikke 'passer ind' og derved ramler ind i kategoriernes grænser 'slås' med en samlet infrastruktur, størstedelen af befolkningen anskuer som praktisk og velfungerende og derfor sjældent vil tænke videre over. Beslutningsforslag, der indstiller til større fleksibilitet i kønskategorierne eller en total bortskaffelse af dem, bliver derfor opvejet i forhold til en samlet - overvejende velfungerende - infrastruktur, hvilket resulterer i gentagne afvisninger af forslagene. Så selv om de fleste partier i Folketinget har udtrykt forståelse for, at transkønnede er fanget i en svær situation, overskygges denne forståelse af CPR-nummerets positive effekter, som vi ser det hos Vivi Kier. For hvis kønskategorierne gøres mere fleksible eller helt fjernes, har det konsekvenser for hele infrastrukturen - en konklusion som også Dorthe Staunæs når frem til i forhold til produktionen af subjektivering inden for netværk (2004: 5759).

En total afskaffelse af de formelle kønskategorier, som Politikeren og Aktivisten har talt for, vil da heller ikke i sig selv udviske kønnets betydning. Som beskrevet læner disse kategorier sig op ad normative forståelser af køn, der eksisterer ved siden af det institutionaliserede system. Kønnet lovgivning som for eksempel øremærkning af barselsorlov til kvinder og værnepligt for mænd udspringer ikke af det rene ingenting, men er en afspejling af specifikke, normative kønsforståelser. Hvis kønnets betydning for hverdagen i Danmark derfor skal ændres, handler det ikke blot om formelle kønskategorier, men i lige så høj grad om de forståelser af køn, de afspejler.

\section{KONKLUSION}

Artiklen har via infrastrukturbegrebet tydeliggjort, hvordan kønskategorierne indlejres i hverdagen i Danmark og dermed er vedkommende for alle; ikke kun de, der lever i 
kønnenes grænseland. Men det er netop i kønsdikotomiens grænseland, det bliver muligt at kaste lys over den brede sociale ordens arkitektur (Bowker \& Star 2000: 221-223). Det empiriske arbejde i forbindelse med denne artikel har understøttet argumentet om, at kønskategorierne er blevet selvfølgelige og deres effekter usynlige der er tale om "en ikke-debat", som Talspersonen definerede det. For selv om køn er på dagsordenen hos for eksempel mange politiske partier i forbindelse med ligeløn, kvoter, etc., er det kun enkelte politikere, der mener, at selve kønsopdelingen af borgerne og betydningerne af denne er relevant af diskutere.

Omvendt nærværende er kønskategorierne og deres betydning for transkønnede borgere, der må betale prisen for en velfungerende infrastuktur. For den negative slagside af infrastrukturens indtrængen $i$ alle hjørner af hverdagen er, at de der ikke 'passer ind' $i$ infrastrukturens kategorier ligeledes i alle hjørner af hverdagen støder på kønskategoriernes grænser:

"De der oplevelser af, at jeg hele tiden ikke kunne få lov at, hvad skal man sige, udleve min kvindelige side uden hele tiden at blive mindet om.. at offentligheden hele tiden sagde: Det kan du godt glemme - du er en mand, i form af mine id-papirer, mit pas, mit kørekort, alle vegne.” (Kønsterroristen)

Når kønsklassificeringen anskues ud fra et infrastrukturperspektiv, bliver det muligt at forklare den fraværende debat omkring kønskategorierne og begrunde transkønnedes svære situation og manglende politiske opbakning som en konsekvens af kønskategoriernes status som ufravigelige og uforanderlige inden for rammerne af CPR. Ufravigelige fordi en lang række forhold, strukturer og praksisser i samfundet er afhængig af utvetydig kønsklassificering. Uforanderlige fordi de er baseret på en kønsforståelse, der opstiller køn som en medfødt og biologisk determineret omstændighed og der- med ikke levner plads til fleksibilitet mellem eller i kategorierne.

Kategorier er dog ikke statiske størrelser, der består uanfægtet af virkelighedens mangfoldighed og praksisser. Men der er behov for diskussion og refleksion omkring deres grundlag førend deres deltagelse i konstruktionen af selvfølgeligheder og lidelse kan synliggøres inden for rammerne af en usynlig infrastruktur.

\section{NoTER}

1. Transkønnethed er overtaget fra og anvendt om selvidentificerede transkønnede personer. Begrebet skal forstås med en bred og inkluderende betydning, der henviser til personer, som kønsmæssigt "understand cross-identification as a crucial part of their gendered self but they may pick and choose among the options of body modification, social presentation and legal recognition available to them" (Judith Halberstam, citeret i Jagose 1999). 2. Interviewene med de seks informanter blev gennemført i foråret 2010, de var alle semistrukturerede og havde en varighed af 37 til 102 minutter. En grundig redegørelse af undersøgelsens empiriske grundlag og de metodiske og etiske overvejelser herover fremgår af specialeafhandlingen Køn som infrastruktur, der blev afleveret ved Københavns Universitet i oktober 2010.

3. Da spørgsmålet om kønskategoriens synlighed i CPR-nummeret vil kræve andre teoretiske redskaber end de, der inddrages i denne artikel, vil dette kritikpunkt ikke blive behandlet her.

4. Af lovgivningen fremgår det, at de registrerede oplysninger skal omfatte personnummer, navn, adresse, køn, fødselsregistrering, statsborgerskab, medlemskab af folkekirken, slægtskab og civilstand; i alle henseender både nutidigt og historisk (LBK 878 af 14/09/2009).

5. Forståelsen af CPR som en infrastruktur, der er baseret på et ret unikt, dansk registreringssystem, vil tillige kunne bidrage med nogle interessante, komparative konklusioner ift. mulighederne for at skifte kønskategori eller endda bryde med den dikotomiske opdeling, som f.eks. i Indien. 


\section{LITTERATUR}

- 1. behandling af B $6507 / 08$ : Forslag til folketingsbeslutning om transseksuelles/transkønnedes rettigheder. Lokaliseret den 10/6 2010 på http://www.ft.dk/samling/20072/beslutningsforslag/B65/BEHl/forhandling.htm\#dok - 1. behandling af B 142 06/07: Forslag til folketingsbeslutning om transseksuelles/transkønnedes rettigheder. Referat fra Folketingets hjemmeside, lokaliseret den 10/6 2010 på http://www.ft.dk/samling/2006l/beslutningsforslag/bl42/behl/1/forhandling.htm?startItem $=$

. B 65 07/08: Forslag til folketingsbeslutning om transseksuelles/transkønnedes rettigheder. Lokaliseret den 10/6 2010 på http://www.ft.dk/samling/20072/beslutningsforslag/B65/som_fremsat.htm

- B 142 06/07: Forslag til folketingsbeslutning om transseksuelles/transkønnedes rettigheder. Lokaliseret den $10 / 6$ på http://www.ft.dk/sam-

ling/20061/beslutningsforslag/B142/som_fremsat.htm\#dok

- B 168 09/10: Forslag til folketingsbeslutning om forbedring af transkønnedes rettigheder. Lokaliseret den 10/6 2010 på http://www.ft.dk/samling/20091/beslutningsforslag/B168/index.htm - Bowker, Geoffrey C. \& Star, Susan Leigh (2000, org. 1999): Sorting Things Out. Classification and Its Consequences. The MIT Press, Massachusetts Institute of Technology, Cambridge \& London. - Butler, Judith (1990): Gender Trouble. Feminism and the Subversion of Identity. Routledge, New York \& London.

. Butler, Judith (2004): Undoing Gender. Routledge, New York \& London.

. Foucault, Michel (1981, org. 1978): Indledning, i Herculine Barbin: Af en hermafrodits bekendelser. Rhodos, København.

- Foucault, Michel (1994, org. 1976): Viljen til viden. Seksualitetens historie 1. Det lille forlag, Frederiksberg.

- Jagose, Annamarie (1999): Masculinity Without Men, i Genders Journal nr. 29/1999. University of Colorado. Lokaliseret den 2/8 2010 på http://www.genders.org/g29/g29_halberstam.ht $\mathrm{ml}$

- LBK 878 af 14/09/2009: Bekendtgørelse af lov om Det Centrale Personregister. Lokaliseret den $16 / 72010$ på https://www.retsinformation.dk/Forms/R0710.a spx?id=125606
- Lee, Rosa (2006): Why Feminists Are Wrong. How Transsexuals Prove Gender Is Not A Social Construction. Xlibris Corporation, Bloomington. - Star, Susan Leigh (1991): Power, Technologies and the Phenomenology of Conventions: on Being Allergic to Onions, i John Law (eds.): A Sociology of Monsters. Essays on Power, Technology and Domination. Routledge, London.

- Staunæs, Dorthe (2004) Køn, etnicitet og skoleliv. Forlaget Samfundslitteratur, Frederiksberg.

- Søndergaard, Dorte Marie (2000): Destabiliserende diskursanalyse - veje ind i poststrukturalistisk inspireret empirisk forskning, i Hanne Haavind (red.): Kön och tolkning. Metodiska möjligheter $i$ kvalitativ forskning. Natur och Kultur, Stockholm. - Whatmore, Sarah J. (2009): Mapping Knowledge Controversies: Science, Democracy and the Redistribution of Expertise, i Progress in Human Geography, Oktober 200933 (5).

\section{SUMMARY}

Gender as infrastructure

Based on the theoretical conception of 'infrastructure' the article explores how gender can be understood in the context of the Danish information infrastructure CPR, which registers all Danish citizens. Specific to this information system is that it produces gender specific ID-numbers for citizens, which are then used to structure the Danish welfare system. Installed in this omnipotent system, the gender categories create a needed order in everyday life and, thus, become invisible.

But for transgendered citizens, who live in and embody the boarderland between 'male' and 'female', the categories become highly visible as they become a source of suffering due to the infrastructure's requirement of clear gender categorizations, either/or. However, these categorizations can not be easily cast away as they are based on normative understandings of gender as a biological fact.

Beate Sløk-Andersen

cand.mag. i Europæisk Etnologi 